\title{
Potential of Cordyline sp Plant for Remediation of Metal-Leachate Contaminated Soil
}

\author{
B. Jayanthi, C. U. Emenike, P. Agamuthu, and S. H. Fauziah
}

\begin{abstract}
Heavy metals are extremely persistent in the environment and cannot degrade through chemical process, hence the long term accumulation cause induce to the environment. Soil is one of the major sink to heavy metal contamination due human activities associated to the development of global economies. Metals from waste stream, especially landfill leachate impact the soil and there is need to develop remedial option for the environmental safety of soil core. Various plants have been used to remedy polluted soil, yet metal interaction with plant differ with respect to medium or source of metal pollution. Phytoremediation technology is an alternative and cheaper approach for remediation of metal contaminated soil. Plant-based remediation is one of the most significant sustainable techniques to cope with overwhelming consequences of pollutants. Therefore this study aimed to study the potential of Cordyline sp plant and Durianta variegated for the phytoremediation of heavy metals ( $\mathrm{Pb}, \mathrm{As}, \mathrm{Mn}, \mathrm{Ni}$, and $\mathrm{Cr}$ ) from the leachate contaminated soil. The results showed that Cordyline sp plants tends to accumulate high amounts of this metals compared to Durianta variegated and control. Cordyline sp was able to remove $63 \%$ of $\mathrm{Pb}, 90 \%$ of $\mathrm{As}, 78.8 \%$ of $\mathrm{Mn}$, $88.9 \%$ of $\mathrm{Ni}$ and $75 \%$ of $\mathrm{Cr}$ from the metal polluted soil. The removal of heavy metal from the contaminated soil was significantly higher compared to control at $P>0.05$. The highest heavy metal removal rate constant was obtained for As and $\mathrm{Ni}$ at same rate of $0.018 \mathrm{mg} / \mathrm{kg} \mathrm{day}^{-1}$ when Cordyline sp plants were used. Therefore we can conclude that, Cordyline sp have a potential to remediate heavy metal contaminated soil at a significant level.
\end{abstract}

Index Terms-Heavy metal, landfill soil, leachate, phytoremediation.

\section{INTRODUCTION}

Heavy metal contamination in the environment is a worldwide phenomenon that requires serious attention [1]. This is mainly due to geologic and anthropogenic activities. Landfilling is identified as one of major contributor to heavy metal contamination to the environment [2]. The high waste generation pattern in especially in developing generation leads to high generation of landfill leachate. Landfill leachate is highly concentrated complex effluents which contains organics: alkenes, aromatic hydrocarbons, acids, esters, alcohols, hydroxyl benzene, amides, and others, ammonia,

Manuscript received December 5, 2016; revised May 20, 2017. This work was supported by the University of Malaya Research Grant (RP011A-14SUS), Centre of Research Grant Management (PG070-2014B) and Ministry of Higher Education (Mybrain15).

The authors are with Institute of Biological Sciences, Faculty of Science, University of Malaya Kuala Lumpur, Malaysia (e-mail: jayne_barath@yahoo.com,_ emenike@um.edu.my, profagamuthu@gmail.com, fauziahsh@um.edu.my). nitrogen and heavy metals such as cadmium, chromium, copper, lead, zinc, and nickel [3]. The industrialization and urbanization that has progressively developed over time without any regard for environmental consequences. The indiscriminate release of heavy metals into the soil is major health concern globally, as the heavy metal cannot be broken down or transform to non-toxic form easily. Most of the heavy metal are human carcinogenic even at low concentration [4]. Due to the high degree of toxicity, $\mathrm{As}, \mathrm{Cd}, \mathrm{Cr}, \mathrm{Pb}$ and $\mathrm{Hg}$ rank among the most toxic metals that are of public health significance. Heavy metals are systemic toxicants that are known to cause multiple organ damage, even at lower levels of exposure. They are also classified as human carcinogens (known or probable) according to the U.S. Environmental Protection Agency, and the International Agency for Research on Cancer. Most of the Asian countries are surrounded by water bodies and expanse of fertile land that serve as serene environment for aquatic organisms [5]. Phytoremediation is an aspects that uses plant for treatment of heavy metal contaminated soil. An effective phytoremediation occurs when the pollutants is within the root zone of the plant [6] and [7]. About 420 species from 45 plants have been were identified as hyper accumulators of heavy metals [8]. This study evaluated potential of two selected plants in towards uptake of heavy metals from leachate contaminated soil.

\section{MAterials And Methodology}

\section{A. Soil and Leachate Characterization}

Soil samples were collected from Taman Beringin (TBL) (30 $13.78 \mathrm{~N}$; $101039.72^{\prime} \mathrm{E}$; non-operational) landfills at $30 \mathrm{~cm}$ depth in accordance with the 2014 ASTME-1197 [9], [10], and [11]. The sample were analyzed for $\mathrm{pH}$ using a multiprobe meter (YSI Professional Plus, USA), while the soil total nitrogen, total potassium, and total phosphorus were analyzed by adopting ASTM E778-87, ASTM E96-94, and ASTM D5198-92 methods, respectively. Meta concentrations were analyzed based on the USEPA 3050B guidelines except for mercury $(\mathrm{Hg})$, which was analyzed based on the USEPA 3052 method. Leachate samples were also collected from the landfill and analyzed for parameters similar to the soil samples. Physico-chemical properties of the leachate samples determined in the laboratory were $\mathrm{BOD}_{5}, \mathrm{COD}$, total $\mathrm{N}, \mathrm{P}$, and K. The analysis was conducted based on APHA (1998) standards [10].

\section{B. Phytoremediation Experimental Design}

The leachate contaminated soil from Taman Beringin 
Landfill was collected for the phytoremediation study and the heavy metal concentration was predetermined before the set up. The phytoremediation potential of two plant were tested in this study (Table I). Plants were obtained from University of Malaya Nursery, Kuala Lumpur, Malaysia. Each plant was placed in polybag containing $2.25 \mathrm{~kg}$ of leachate contaminated soil with predetermined heavy metal concentration. Experiment was conducted for 120 days. Soil microcosm without any plant served as the control experiment The initial and final concentration of metals were respectively analyzed before and after the experiments for the plants and soil.

TABLE I: DESCRIPTION OF TREATMENT

\begin{tabular}{|l|l|l|}
\hline Treatment & Details of treatment & No of Samples \\
\hline A & $2.25 \mathrm{Kg}$ of TB Soil + Cordyline & 3 \\
\hline B & $2.25 \mathrm{Kg}$ of TB Soil + Durianta variegated & 3 \\
\hline C & $2.25 \mathrm{~kg}$ of TB Soil (Control) & 3 \\
\hline
\end{tabular}

\section{Heavy Metal Analysis}

Soil and plant heavy metal concentration was analysed for all the treatment using ICP-OES according to USEPA 3050B guidelines [10].

\section{Rate Constant of Heavy Metal Removal}

Rate of metal uptake in a day was calculated using first order kinetic models

$$
K=-\frac{1}{t}\left(\ln \frac{c}{c_{0}}\right)
$$

$K=$ first-order rate constant for metal uptake per day

$t=$ time in days

$C=$ concentration of residual metal in the soil $\left(\mathrm{mg} \mathrm{kg}^{-1}\right)$

$C_{0}=$ initial concentration of metal in the soil $\left(\mathrm{mg} \mathrm{kg}^{-1}\right)$

\section{E. Uptake Modelling of Heavy Metal}

The uptake of heavy metals by plant from soil was calculated with bioaccumulation factor (BAF) and translocation factor $(\mathrm{TF})$,

$$
\mathrm{BAF}=\frac{\text { Heavy mental in plant }}{\text { Heavy mental in soil }}
$$

$\mathrm{BAF}=$ Bioaccumulation factor

Heavy metal in plant= Concentration of heavy metal in harvested part of plant $(\mathrm{mg} / \mathrm{kg})$

Heavy metal in soil $=$ Concentration of heavy metal in soil $(\mathrm{mg} / \mathrm{kg})$

$$
\text { TFshoot }=\frac{\text { Mental in shoot }}{\text { Mental in root }}
$$

$\mathrm{TF}=$ Translocation factor

Metal in shoot $=$ Concentration of heavy metal in shoot of plant $(\mathrm{mg} / \mathrm{kg})$

Metal in root $=$ Concentration of heavy metal in root of plant $(\mathrm{mg} / \mathrm{kg})$

\section{RESULTS AND DISCUSSION}

Taman Beringin Landfill is a closed non-sanitary landfill.
The operation of the landfill ended in 2005 and was receiving about 1800 to 2000 tonnes of MSW daily. Leachate and soil characterization is tabulated in Table II and Table III. Landfill leachate of Taman Beringin landfill contained heavy metals above the discharge limit from the standard of Environmental Quality Regulations 2009, Malaysia. Similarly the soil characterization also showed that heavy metal concentration in Taman Beringin Landfill is above the prescribed limit [12]. The concentration of heavy metal in soil followed the order of $\mathrm{Al}(49600 \mathrm{mg} / \mathrm{L})>\mathrm{Fe}(42900 \mathrm{mg} / \mathrm{L})>\mathrm{Mn}(281 \mathrm{mg} / \mathrm{L})>\mathrm{As}$ $(141 \mathrm{mg} / \mathrm{L})>\mathrm{Cu}(59 \mathrm{mg} / \mathrm{L})>\mathrm{Zn}(49 \mathrm{mg} / \mathrm{L})>\mathrm{Cr}(46 \mathrm{mg} / \mathrm{L})>$ $\mathrm{Ni}(21 \mathrm{mg} / \mathrm{L})>\mathrm{Pb}(18 \mathrm{mg} / \mathrm{L})>\mathrm{Hg}(0.02 \mathrm{mg} / \mathrm{L})>\mathrm{Cd}(0.01$ $\mathrm{mg} / \mathrm{L})$. The metal distributions among the specific forms

\begin{tabular}{|c|c|c|c|}
\hline $\begin{array}{l}\text { Test } \\
\text { Parameters }\end{array}$ & Method & $\begin{array}{l}\text { Range } \\
\text { values } \\
(\mathrm{mg} / \mathrm{L})\end{array}$ & $\begin{array}{l}\text { Standard } \\
\text { (Environmental } \\
\text { Quality Regulations } \\
\text { 2009, Malaysia) }\end{array}$ \\
\hline pH & $\begin{array}{l}\text { Probe } \\
\text { insertion }\end{array}$ & $7.57 \pm 0.8^{*}$ & 6.0-9.0 \\
\hline BOD & $\begin{array}{l}\text { APHA } \\
5210 \text { B }\end{array}$ & $127 \pm 45$ & 20 \\
\hline COD & $\begin{array}{l}\text { APHA } \\
5220\end{array}$ & $482 \pm 103$ & 400 \\
\hline Total N & $\begin{array}{l}\text { ASTM } \\
\text { E778-87 }\end{array}$ & $\begin{array}{ll}0.25 & \pm \\
0.08^{*} & \\
\end{array}$ & 5 \\
\hline Total K & $\begin{array}{l}\text { ASTM } \\
\text { E926-94 }\end{array}$ & $11.6 \pm 2.1$ & N.A \\
\hline Total P & $\begin{array}{l}\text { ASTM } \\
\text { D5198-92 }\end{array}$ & $24.3 \pm 0.7$ & N.A \\
\hline As & $\begin{array}{l}\text { USEPA } \\
3050 \mathrm{~B}\end{array}$ & 0.01 & 0.05 \\
\hline $\mathrm{Ca}$ & $\begin{array}{l}\text { USEPA } \\
3050 \mathrm{~B} \\
\end{array}$ & $242.1 \pm 42$ & N.A \\
\hline $\mathbf{F e}$ & $\begin{array}{l}\text { USEPA } \\
3050 \mathrm{~B} \\
\end{array}$ & $134.6 \pm 16$ & 5.0 \\
\hline Mn & $\begin{array}{l}\text { USEPA } \\
3050 \mathrm{~B} \\
\end{array}$ & $3.1 \pm 0.32$ & 0.2 \\
\hline Mg & $\begin{array}{l}\text { USEPA } \\
3050 \mathrm{~B} \\
\end{array}$ & $52.2 \pm 8.7$ & N.A \\
\hline $\mathrm{Na}$ & $\begin{array}{l}\text { USEPA } \\
3050 \mathrm{~B}\end{array}$ & $29.7 \pm 5.1$ & N.A \\
\hline $\mathrm{Cu}$ & $\begin{array}{l}\text { USEPA } \\
3050 \mathrm{~B}\end{array}$ & $0.5 \pm 0.1$ & 0.2 \\
\hline $\mathbf{Z n}$ & $\begin{array}{l}\text { USEPA } \\
3050 \mathrm{~B}\end{array}$ & $24.3 \pm 3$ & 2.0 \\
\hline $\mathbf{P b}$ & $\begin{array}{l}\text { USEPA } \\
3050 \mathrm{~B}\end{array}$ & $<0.01$ & 0.10 \\
\hline Cd & $\begin{array}{l}\text { USEPA } \\
3050 \mathrm{~B}\end{array}$ & $0.4 \pm 0.1$ & 0.01 \\
\hline $\mathrm{Hg}$ & $\begin{array}{l}\text { USEPA } \\
3052\end{array}$ & 0.03 & 0.005 \\
\hline $\mathrm{Cr}$ & $\begin{array}{l}\text { USEPA } \\
3050 \mathrm{~B}\end{array}$ & $6.2 \pm 1.4$ & 0.20 \\
\hline $\mathrm{Ni}$ & $\begin{array}{l}\text { USEPA } \\
3050 \mathrm{~B}\end{array}$ & $0.85 \pm 0.1$ & 0.20 \\
\hline Al & $\begin{array}{l}\text { USEPA } \\
3050 \mathrm{~B}\end{array}$ & $5.47 \pm 1.2$ & N.A \\
\hline
\end{tabular}
differs based on their chemical properties and characteristics of the soil [11], [13].

(Mean values $n=3) *$ All parameters are in $\mathrm{mg} / \mathrm{L}$ except $\mathrm{pH}$ and Total $\mathrm{N}(\%)$ 
TABLE III: SOIL CHARACTERIZATION OF TAMAN BERINGIN LANDFILL

\begin{tabular}{|l|l|l|l|}
\hline Test parameter & Units & Test method & $\begin{array}{l}\text { Taman Beringin } \\
\text { landfill }\end{array}$ \\
\hline & & & Mean $^{\mathrm{a}}$ \\
\hline $\mathbf{p H}$ & & Probe Insertion & 7.57 \\
\hline Total N & $\%$ & ASTM E778-87 & 0.62 \\
\hline Total K & $\mathrm{mg} / \mathrm{kg}$ & ASTM E926-94 & 396.9 \\
\hline Total P & $\mathrm{mg} / \mathrm{kg}$ & ASTM & 568 \\
\hline As & $\mathrm{mg} / \mathrm{kg}$ & USEPA 3050 B & 141 \\
\hline $\mathbf{C a}$ & $\mathrm{mg} / \mathrm{kg}$ & USEPA 3050 B & 1608 \\
\hline $\mathbf{F e}$ & $\mathrm{mg} / \mathrm{kg}$ & USEPA 3050 B & 42900 \\
\hline $\mathbf{M n}$ & $\mathrm{mg} / \mathrm{kg}$ & USEPA 3050 B & 281 \\
\hline $\mathbf{M g}$ & $\mathrm{mg} / \mathrm{kg}$ & USEPA 3050 B & 127.2 \\
\hline $\mathbf{N a}$ & $\mathrm{mg} / \mathrm{kg}$ & USEPA 3050 B & 4.54 \\
\hline $\mathbf{C u}$ & $\mathrm{mg} / \mathrm{kg}$ & USEPA 3050 B & 59 \\
\hline $\mathbf{Z n}$ & $\mathrm{mg} / \mathrm{kg}$ & USEPA 3050 B & 49 \\
\hline $\mathbf{P b}$ & $\mathrm{mg} / \mathrm{kg}$ & USEPA 3050 B & 18 \\
\hline $\mathbf{C d}$ & $\mathrm{mg} / \mathrm{kg}$ & USEPA 3050 B & $<0.01$ \\
\hline $\mathbf{H g}$ & $\mathrm{mg} / \mathrm{kg}$ & USEPA 3052 & $<0.02$ \\
\hline $\mathbf{C r}$ & $\mathrm{mg} / \mathrm{kg}$ & USEPA 3050 B & 46 \\
\hline $\mathbf{N i}$ & $\mathrm{mg} / \mathrm{kg}$ & USEPA 3050 B & 21 \\
\hline $\mathbf{A l}$ & $\mathrm{mg} / \mathrm{kg}$ & USEPA 3050 B & 49600 \\
\hline
\end{tabular}

Table IV shows the soil initial and residual concentration of heavy metals from the phytoremediation experiment on the contaminated soil. For As, highest removal was observed with Treatment A. Initial As concentration was $141 \mathrm{mg} / \mathrm{kg}$ and residual concentration after 120 days experiment is 15.67 $\mathrm{mg} / \mathrm{kg}$. Statistical analysis shows a significant difference between Treatment $\mathrm{A}$ and the control at $\mathrm{p}>0.05$. Similar trends were observed for almost all the metals studied, whereby Treatment A, Cordyline sp showed highest heavy metal removal activity compared to Treatment B (Durianta variegated) as well as the control. The differences in the removal activity of the phytoextraction may have been due to the different plant species, solubility, and plant uptake [14]. The degree of $\mathrm{Pb}$ reduction after 120 days was highest with Treatment A, whereby it reduced or removed $63 \%$ of $\mathrm{Pb}$ from the contaminated soil $(18 \mathrm{mg} / \mathrm{kg}$ it reduce to $6.67 \mathrm{mg} / \mathrm{kg})$, whereas Treatment B and control recorded $55.5 \%$ and $53 \%$ removal, respectively. The potential of Cordyline sp to remove the $\mathrm{Pb}$ metal in soil showed its ecological importance [8] and supported by another findings by Perumal [15] reported that the Cyperus rotundus and Ludwigea sp able to removed $60 \%$ of $\mathrm{Cr}$ from a contaminated soil without supplements of organic wastes. Treatment A shows an significant removal of $\mathrm{Mn}$ from the contaminated soil. It was removed $78.8 \%$ of $\mathrm{Mn}$ from the soil whereas Treatment B was only able to remove $69 \%$ and control $65 \%$. The rate of metal uptake with Treatment A was higher than Treatment B and could be due to differences in physiology of the plants or growth rate and higher biomass of the plant. An effective bioremediation of metal is when the metal is removed at more than $65 \%$ [16]. The removal of $\mathrm{Ni}$ from the leachate contaminated soil again revealed that higher removal was recorded when Treatment A plant was used in this study. The initial $\mathrm{Ni}$ concentration was $21 \mathrm{mg} / \mathrm{kg}$ and after 120 days of phytoremediation the Ni concentration reduced to $2.33 \mathrm{mg} / \mathrm{kg}$ and percentage of $\mathrm{Ni}$ removal was $88.9 \%$. In the case of $\mathrm{Cr}$, Treatment A was able to remove $75 \%$ of $\mathrm{Cr}$ from the initial of $46 \mathrm{mg} / \mathrm{kg}$ and control only removed $67 \%$ only.

$\mathrm{BCF}$ is the measurement of the metal accumulation efficiency and indicates the capacity of metal accumulation in relation to plant biomass [17]. The bioconcentration factor was higher in Treatment A for all the five metal tested compared to Treatment B (Table V). The differences in the results might be due to the use of different plants which indicates that Treatment A showed more effective accumulation of metals in the plant tissue compared to Treatment B. However the Translocation factor of shoot in Treatment B shows higher factor compared to Treatment A for $\mathrm{Pb}$ and $\mathrm{Cr}$ and while $\mathrm{TF}$ of root was higher in Treatment $\mathrm{B}$ for As, Mn and Ni. This indicates that the shoot of Treatment $\mathrm{B}$ accumulated higher amount of metals compared to Treatment A.

TABLE IV: INITIAL AND RESIDUAL CONCENTRATIONS OF HEAVY METALS FROM THE PHYTOREMEDIATION OF TAMAN BERINGIN LANDFILL LEACHATE CONTAMINATED SOIL

\begin{tabular}{|l|l|l|l|l|}
\hline $\begin{array}{l}\text { Heavy } \\
\text { metals }\end{array}$ & $\begin{array}{l}\text { Initial } \\
\text { Concentrations } \\
(\mathbf{m g} / \mathbf{k g})\end{array}$ & \multicolumn{3}{|l|}{ Mean Residuals Concentrations(mg/kg) } \\
\hline & & $\begin{array}{c}\text { Treatment } \\
\mathbf{A}\end{array}$ & $\begin{array}{l}\text { Treatment } \\
\text { B }\end{array}$ & $\begin{array}{c}\text { Treatment } \\
\text { C }\end{array}$ \\
\hline $\mathbf{A s}$ & 141 & 15.67 & 19 & 28 \\
\hline $\mathbf{M n}$ & 281 & 59.33 & 83 & 96.33 \\
\hline $\mathbf{P b}$ & 18 & 6.67 & 8 & 8.33 \\
\hline $\mathbf{C r}$ & 46 & 11.67 & 12.67 & 15 \\
\hline $\mathbf{N i}$ & 21 & 2.33 & 3 & 3.67 \\
\hline
\end{tabular}

TABLE V: BIOACCUMULATION AND TRANSLOCATION FACTOR OF METALS UPTAKES DURING PHYTOREMEDIATION

\begin{tabular}{|l|l|l|l|l|l|l|}
\hline $\begin{array}{l}\text { Heavy } \\
\text { metals }\end{array}$ & \multicolumn{3}{|c|}{ Treatment A } & \multicolumn{3}{c|}{ Treatment B } \\
\hline & BAF & TF $_{\text {Shoot }}$ & TF $_{\text {Root }}$ & BAF & TF $_{\text {Shoot }}$ & TF $_{\text {Root }}$ \\
\hline As & 2.03 & 0.523 & 1.90 & 2.01 & 0.35 & 2.81 \\
\hline Mn & 0.927 & 0.586 & 1.70 & 0.38 & 0.54 & 1.82 \\
\hline Pb & 0.848 & 0.30 & 3.25 & 0.366 & 0.479 & 2.08 \\
\hline Cr & 0.51 & 0.28 & 3.56 & 0.19 & 0.66 & 1.5 \\
\hline $\mathbf{N i}$ & 1.40 & 0.40 & 2.47 & 1.20 & 0.36 & 2.73 \\
\hline
\end{tabular}

Treatments with plants as metal accumulator have higher heavy metal removal potential than the control experiment. The reduction of metals in Treatment $\mathrm{C}$, which act as control in this experiment can be due to the natural bio attenuation activity in the soil [10]. The heavy metal removal rate is shown in Table VI. First order kinetic model was used to calculate the removal rate of metal by the plant. Comparison between the different treatments across different metals, revealed that the highest removal rate was found in Treatment 
A for As and Ni. The removal rate was at $0.018 \mathrm{mg} / \mathrm{kg} \mathrm{day}^{-1}$. Also, Treatment A recorded the highest removal rate for all other three metals as well. For Mn $\left(0.013 \mathrm{mg} / \mathrm{kg} \mathrm{day}^{-1}\right), \mathrm{Pb}$ $\left(0.008 \mathrm{mg} / \mathrm{kg} \mathrm{day}^{-1}\right)$ and $\mathrm{Cr}\left(0.011 \mathrm{mg} / \mathrm{kg} \mathrm{day}^{-1}\right)$. The results showed that an optimum metal uptake rate was with Treatment A.

TABLE VI: HEAVy METAL REMOVAL RATE FOR DifFERENT TREATMENT $\left(\mathrm{MG} / \mathrm{KG} \mathrm{DAY}^{-1}\right)$

\begin{tabular}{|l|l|l|l|}
\hline Metal & Treatment A & Treatment B & Treatment C \\
\hline As & 0.018 & 0.016 & 0.013 \\
\hline $\mathbf{M n}$ & 0.013 & 0.010 & 0.009 \\
\hline $\mathbf{P b}$ & 0.008 & 0.006 & 0.006 \\
\hline $\mathbf{C r}$ & 0.011 & 0.010 & 0.009 \\
\hline $\mathbf{N i}$ & 0.018 & 0.016 & 0.014 \\
\hline
\end{tabular}

\section{CONCLUSION}

Metal contamination is widespread in soil exposed to leachate from non-sanitary landfills or open dump. The metal concentrations was above the recommended limit. However, certain hyper accumulator plant shows an survival and uptake the metals from the contaminated soil at significant rate. Cordyline sp demonstrated as a potential plant for remediation of leachate contaminated soil.

\section{REFERENCES}

[1] S. C. Wong, X. D. Li, G. Zhang, S. H. Qi, and Y. S. Min, "Heavy metals in agricultural soils of the Pearl River Delta, South China" Environmental Pollution, vol. 119, pp. 33-44, 2002.

[2] P. Agamuthu, C. W. Yee, S. Rahedah, T. Nithyarubini, L. B. Tien, and B. Jayanthi, "Enhancement of landfill methane oxidation using different type of organic Wastes," Environmental Earth Sciences, vol. 73, no. 5, pp. 2489-2496, 2014.

[3] C. U. Emenike, S. H. Fauziah, and P. Agamuthu, "Whole effluent toxicity of active and inactive landfills: Variation of leachate impact on fish (Pangasius sutchi)," Advance Science Letter, vol. 19, no. 9, pp. 2681-2689, 2013.

[4] D. Ruchita, P. Diby et al., "Bioremediation of Heavy Metals from Soil and Aquatic Environment: An Overview of Principles and Criteria of Fundamental Processes," Journal of Sustainability, vol. 7, pp. 2189-2212, 2015.

[5] B. Jayanthi, C. U. Emenike, P. Agamuthu, S. Khanom, M. Sharifah, and S. H. Fauziah "Selected microbial diversity of contaminated landfill soil of Peninsular Malaysia and the behavior towards heavy metal exposure," Catena, vol. 147, pp. 25-31, 2016.

[6] I. A. Garbisu, "Basic concepts on heavy metal soil bioremediation," The European Journal of Mineral Processing and Environmental Protection, vol. 3, no. 1, pp. 58-66, 2003.

[7] G. U. Chibuike and S. C. Obior, "Heavy metal polluted soils: Effect on plants and bioremediation methods," Applied and Environmental Soil Science, vol. 4, no. 3, pp. 1-12, 2014.

[8] F. O. Alaribe and P. Agamuthu, "Assessment of phytoremediation potentials of Lantara camara in $\mathrm{Pb}$ impacted soil with organic waste additives," Ecological Engineering, vol 83, pp. 513-520, 2015.
[9] A.R. Sprocati, C. Alisi et al., " Effectiveness of a microbial formula, as a bioaugmentation agent, tailored for bioremediation of diesel oil and heavy metal co-contaminated soil," Process Biochemistry, vol. 47, no. 11, pp. 1649-1655, 2011.

[10]C. U. Emenike, P. Agamuthu, and S. H. Fauziah "Blending Bacillus sp., Lysinibacillus sp. and Rhodococcus sp. for optimal reduction of heavy metals in leachate contaminated soil," Environmental Earth Sciences, vol. 75, no. 26, pp. 1-8, 2016.

[11] B. Jayanthi, C. U. Emenike, P. Agamuthu, and S. H. Fauziah "Characterization of induced metal responses of bacteria isolates from active non-sanitary landfill in Malaysia," International Biodeterioration\&Biodegradation, 2016.

[12] Department of Environment (DOE), "Contaminated land management and control guidelines No 1: Malaysian recommended site screening levels for contaminated land," Ministry of Natural Resources and Environment Malaysia, 2009.

[13] Y. K. Soon and T. E. Bates, "Chemical pools of cadmium, nickel and zinc in polluted soil and some preliminary indications of their availability to plants," Journal of Soil Science, vol. 33, pp. 477- 488, 1981.

[14] D. Arezoo and P. Agamuthu, "Phyto-enhanced remediation of soil co-contaminated with lead and diesel fuel using biowaste and Dracaena reflexa: A laboratory study," Waste Management \& Research, vol. 34, pp. 246-253, 2015.

[15] S. Perumal, C. Alagappan, S. G Kaliyaperumal, U. Pachikkaran, and B. Logalakshmanan, "Chromium stress in paddy: (i) Nutrient status of paddy under chromium stress; (ii) Phytoremediation of chromium by aquatic and terrestrial weeds," Comptes Rendus Biologies, vol. 333, no. 8, pp. 597-607, 2010.

[16] A. G. Babu, J. Kim, and B. Oh, "Enhancement of heavy metal phytoremediation by Alnus firma with endophytic Bacillus thuringiensis GDb-1," Journal of Hazardous Materials, vol. 250-251, pp. 447-483, 2013

[17] K. V. Santosh, A. A. Juwarkar, G. P. Kumar, P. R. Thawale, S. K. Singh, and T. Chakrabarti, "Bioaccumulation and phyto-translocation of arsenic, chromium and zinc by Jatropha curcas L.: Impact of dairy sludge and biofertilizer," Bioresource Technology, vol. 100, pp. 4616-4622, 2009.

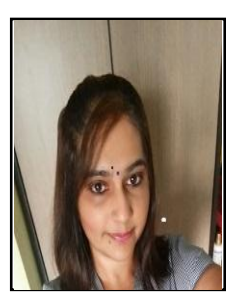

Jayanthi Barasarathi was born in Teluk Intan, Perak, Malaysia on November 8th 1986. She did her B.Sc with honours in Biotechnology field at University of Industrial Selangor in 2009 and her M.Sc in the field of Environmental Biotechnology in year 2013 at University of Malaya, Malaysia.

She is presently a full time doctoral degree student at University of Malaya, Malaysia. She was previously worked as Environmental consultant in a private company, R Sync Technical Resources in year 2013. Her doctoral degree is fully sponsored by Ministry of Higher Education of Malaysia under programme of MyBrain15. She also have published several articles in high ranking journal which includes, Characterization of induced metal responses of bacteria isolates from active non-sanitary landfill in Malaysia in International Biodeterioration \& Biodegradation, Selected microbial diversity of contaminated landfill soil of Peninsular Malaysia and the behavior towards heavy metal exposure in Catena and few more. Her research interest is on bioremediation, phytoremediation, environmental microbiology, and environmental biotechnology and leachate studies. Miss Jayanthi is also a member of Malaysian Society of Waste Management and Environment and Alam Sekitar Malaysia. She has been actively involved in organizing international conferences, workshop and seminars. 